\title{
The development of Schoology web-based learning media with GeoGebra to improve the ICT literacy on quadratic functions
}

\author{
Arif Fatahillah*, Irsalina Dwi Puspitasari, Saddam Hussen \\ Department of Mathematics Education, University of Jember, Indonesia \\ *Corresponding author: arif.fkip@unej.ac.id
}

\section{ARTICLE INFO}

Article history:

Received: 14 April 2020

Revised: 24 June 2020

Accepted: 30 June 2020

Published online: 18 Agustus

2020

Published regularly: October 2020

\begin{abstract}
The use of technology in learning is essential for developing students' ICT literacy. However, the application of technology as a learning media remains limited. The purpose of this study is to develop a learning media to enhance students' ICT literacy. This research is conducted using a 4-D model, which consists of four stages: defining, designing, developing, and disseminating. This learning media is developed based on ICT literacy indicators. The study participants are 33 of 10th-grade students at one of the public vocational schools in Jember, East Java. Data collection methods consist of validation sheets, tests, questionnaires, interviews, and observations. The expert validation is used to validate the media, while the students' response questionnaire determines the practicality. The validity result shows that the media can be used to measure ICT literacy. Moreover, the practicality of media also shows that it can be easily applied. Furthermore, the effectiveness of learning media is obtained from the N-Gain average of test and ICT literacy questionnaire. The observation data also support the effectiveness of the media during the implementation. The result shows that the media confirmed to be effective as it can improve the students' ICT literacy. To sum up, the Schoology web-based learning media with GeoGebra is useful to improve ICT literacy on quadratic functions
\end{abstract}

(C) 2020 Universitas Muhammadiyah Surakarta

\section{Introduction}

The development of technology influences the education sector which makes it easier to understand and makes it more exciting and enjoyable in the learning process (Jan, 2018; Kristanto, Amin, \& Khabibah, 2016; Murtikusuma, Hobri, et al., 2019; Sriyanto \& Kaniadewi, 2019). Therefore, technology must be developed to foster the quality of education, one of which is the application of technology in a learning media (Joshua, Kom, \& $\mathrm{Si}, \underline{2015}$; Oktavianingtyas, Salama, Fatahillah, Monalisa, \& Setiawan, 2018; Rohaeti, Bernard, \& Primandhika, 2019). Learning media is a tool to transform learning material delivery, from a previously abstract concept into a realistic way to improve the students' comprehension and learning outcomes (Rohaeti et al., 2019).

To cite this article:

Fatahillah, A., Puspitasari, I., D. \& Hussen, S. (2020). The development of Schoology web-based learning media with GeoGebra to improve the ICT literacy on quadratic functions. JRAMathEdu (Journal of Research and Advances in Mathematics Education), 5(3), 304-316. doi: https://doi.org/10.23917/jramathedu.v5i3.10692 
Improvement in comprehension and learning outcomes using technology relies on the students' literacy on information and communication technologies (ICT). ICT Literacy is the ability to use digital technology, which consists of five components: access, manage, integrate, evaluate, and create (Garba, 2014). According to Pernia(2008), this ability is one of the supporting factors in education progress. The ICT literacy must be developed in today's education system because it influences students' learning outcomes (Markauskaite, 2006; Tadesse, Gillies, \& Campbell, 2018; Thamnmasaeng, Pupat, \& Petchaboon, 2016). Although the technology affects the students' ICT literacy, the utilization it in the learning process is limited and (Bernard \& Senjayawati, 2019; Nurhabibah, Setiawan, Yanti, Miraj, \& Yannuar, 2018; Wahyu, Ratnasari, Mahfudy, \& Etmy, 2019). Research by Nurhabibah et al. (2018) revealed that school technological facilities are one of the factors that can influence the learning process. However, Pratolo and Solikhati (2020) found that the facilities in school were inadequate, so they could not support the technology-based learning process. Therefore, teachers need to find strategies to utilize technology in the learning process with existing facilities, s toprove the students' ICT literacy (Eliana, Senam, Wilujeng, \& Jumadi, 2016; Markauskaite, 2006; Pratolo \& Solikhati, 2020).

Computers, with the support of the internet and web networks as the products of development in the technology, can be used as the learning media providing meaningful learning experiences to students (Ghavifekr \& Rosdy, 2015). Other research by Setyaningrum (2018) similarly shows that students who learn using the blended learning method have a good understanding of concepts. The study uses web-based learning that provides a variety of contents that supports the learning process, including assignments. Besides, web-based learning is very effective because of its flexibility in terms of time. Students can immediately get feedback on the results after the completion of the task given. Schoology is one of the learning management systems (LMS) that can generate web-based learning, known as e-learning. Besides, it is user-friendly, Schoology has many advantages due to its variety of features (Murtikusuma, Fatahillah, Oktavianingtyas, Hussen, \& Lailiya, $\underline{2019}$ ). Learning through e-learning can enhance students' ICT literacy and is suitable for achieving the learning objectives (Dhayanti, Johar, \& Zubainur, 2018).

Mathematics is an abstract subject that requires media in its learning process. One of the learning materials that many students find difficult to understand is the quadratic function. Based on interviews with teachers, students find it difficult to understand or apply the arithmetic concept and the effect of values $a, b, c$ and discriminant $(D)$ on the graph of quadratic functions $f(x)=a x^{2}+b x+c$. They need to understand and master this learning material since it is a prerequisite to other learning materials in mathematics.

Additionally, computers can also be used to create learning media developed by software that can visualize mathematical concepts. Koklu and Topcu (2012) initiated research using Cabri to visualize the quadratic function graph. GeoGebra is one of the software similar to Cabri. Şandır and Aztekin (2016), in their research, revealed that GeoGebra is more user-friendly than Cabri. As the latest Dynamic Geometry Softwares (DGS), it is also available for download freely, has a holistic approach, and provides a visualization of the Computer Algebra System (CAS) (Şandır \& Aztekin, 2016). This software can help students develop their ideas by manipulating mathematics (Saha, Ayub,

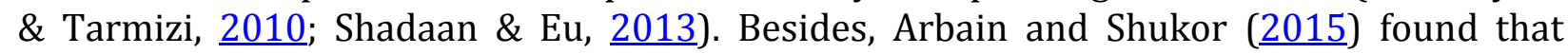
GeoGebra provided a positive impact on the students' achievement.

The use of technology as a learning media influences the ability and skill of students in learning. ICT-based learning or learning by utilizing technology can enhance the 
students' ICT literacy and make the learning process more effective than conventional learning (Eliana et al., 2016). The research by Eliana et al. (ㅁ16) shows that project-based science learning integrated with e-learning can promote the students' ICT literacy. This learning can be applied to fulfill ICT literacy because the students must acquire it as a provision for the future. Additionally, Schoology-assisted learning media with valid, practical, and effective criteria can help students understand the material presented (Murtikusuma, Fatahillah, et al., 2019). Previous studies indicate the advantages of webbased learning media and mathematical software in the learning process. Moreover, previous studies also showed that Schoology and GeoGebra are the user-friendly media in the learning process. These media also influence the students' learning outcomes.

However, previous development research did not show the effectiveness of learning media when GeoGebra software with Schoology web-based learning is incorporated. Previous research (Koklu \& Topcu, 2012) has developed learning media on the quadratic function using Cabri. In this development research, the media will be developed on the same material: quadratic functions, but by using different software, GeoGebra. Therefore, it is necessary to develop and determine the effectiveness of Schoology web-based learning with GeoGebra software on quadratic functions. In general, the effectiveness of learning media is measured by students' learning outcomes after using the media. In this study, the students' ICT literacy is the main focus in measuring media effectiveness. Therefore, the development of the media will be based on the indicators of ICT literacy. This study formulates the problem as follows:

1. What is the development of Schoology web-based learning media using GeoGebra on quadratic functions to enhance the students' ICT literacy?

2. How is the effectiveness of Schoology web-based learning media using GeoGebra software on quadratic functions on the students' ICT literacy?

\section{Research Methods}

This research is development research, which produces a product in the form of learning media. Then, the product is tested for validity, practicality, and effectiveness. The participants in this study are 33 of 10th-grade students at one of the public vocational schools in Jember, East Java. This study used the Thiagarajan model or known as the 4-D model, which consists of four stages: defining, designing, developing, and disseminating (Thiagarajan, Semmel, \& Semmel, 1974). In the defining stage, observations and interviews are carried out to determine the learning process's needs by conducting initial analysis activities, media analysis, and formulation of learning objectives. The designing stage prepares the learning media design (draft I) through several steps, i.e., media selection, format selection, the initial design of the media, and the preparation stage. Observations and interviews are also performed to determine the needs of the learning outcomes tests. Then, the validation and test are carried out at the developing stage.

The media design was validated by two lecturers of the Mathematics Education Study Program and a mathematics teacher. The media can be tested on research subjects after it was declared as valid. The level of practicality (See Table 1) of the media is determined from the questionnaire to obtain the response on media usage. The results of the interviews are also used to support the use of the media. The questionnaire was arranged based on function, ease of operating media, and students' experience when using media. The effectiveness of learning media is obtained from the $\mathrm{N}$-Gain of learning outcomes test and ICT literacy questionnaire that is supported by the results of observation when media 
attempt was carried out. The criteria of the model effectiveness are presented in Table 2 . The media fulfill the criteria of valid, practical, and effective aspects so that the school's disseminating stage is carried out. It is achieved by submitting manuals for making and using Schoology web-based learning media with GeoGebra software on a quadratic function and learning media design on GeoGebra software. The dissemination is carried out through blogs and GeoGebra links.

Table 1

Level of the practicality of the media

\begin{tabular}{cc}
\hline P-Value & Percentage Category \\
\hline $95 \%<\mathrm{P} \leq 100 \%$ & Excellent \\
$80 \%<\mathrm{P} \leq 95 \%$ & Good \\
$65 \%<\mathrm{P} \leq 80 \%$ & Fair \\
$50 \%<\mathrm{P} \leq 65 \%$ & Poor \\
$\mathrm{P} \leq 50 \%$ & Very Poor \\
\hline
\end{tabular}

Table 2

Criteria of Normalized N-Gain Index (Hake, 1999)

\begin{tabular}{cc}
\hline Normalized N-Gain Score & Interpretation \\
\hline $\mathrm{g}>0.7$ & High \\
$0.3 \leq \mathrm{g} \leq 0.7$ & Middle \\
$\mathrm{g}<0.3$ & Lower \\
\hline
\end{tabular}

\section{Results and Discussion}

The learning media was developed using four stages of 4-D model: defining, designing, developing, and disseminating. The description of each stages are as follows:

\section{Defining Stage}

In this stage, the researchers determined the purpose of the development of the Schoology web-based learning media with GeoGebra software was to produce the learning media to help the students in understanding the material and improve their ICT literacy. The activities at this stage are initial analysis, media analysis, and formulation of learning objectives. The initial analysis activities were conducted through observation and interviews with the teachers. The results confirm the conventional approach in the class's Mathematics learning process. Teachers have not fully used the learning media and the technology available that can help teachers and students in the learning process. The analysis also found that students can utilize technology, such as smartphones and computers. Therefore, it is required the use of technology as a learning media that can help students understand the material and enhance their ICT literacy.

In media analysis activities, the researchers found that schools' learning media have not been fully equipped with technology. Therefore, it is necessary to develop effective media to increase students' understanding. The students' ability to use the technology can facilitate an effortless understanding of the material. Media development is carried out by researchers using Schoology and GeoGebra software. Schoology is a media used for information exchange and is equipped with various features that can be utilized in the learning process. Meanwhile, GeoGebra software provides a quick and precise visualization of the graphics.

Furthermore, in the formulation of learning objectives activities, the researchers formulate the objectives to be achieved from the development of this media. The students 
can easily access the learning information. Additionally, the materials presented can be better understood by exploring and manipulating mathematics both independently or guided, and improving their ICT literacy.

\section{Designing Stage}

In this stage, the Schoology web-based learning media with GeoGebra software on quadratic functions is generated through several activities: media selection, format selection, the initial design of the media, and preparation of learning outcomes tests. Media selection using Schoology and GeoGebra software is based on the results of the initial analysis. The purpose of using online media is to facilitate students to learn without time and place restrictions. Therefore, the internet network should be provided well. Furthermore, in the format selection activities, GeoGebra software was developed in the form of "ggb." format, which it is made offline and uploaded to the online GeoGebra account. Once uploaded, this media is linked to Schoology with https://www.schoology.com/page. Learning materials in Schoology can be accessed by users who have joined the Schoology by entering the access code. Additionally, the learning tests are made using the test/quiz feature, which is also linked to Schoology.

The initial design of the media using Schoology and GeoGebra software based on ICT literacy indicators is provided in Table 3. The indicators of ICT literacy are modified and adopted from the Educational Testing Service (ETS) (2002).

Table 3

ICT literacy indicator for each component

\begin{tabular}{|c|c|c|}
\hline $\begin{array}{l}\text { ICT Literacy } \\
\text { Component }\end{array}$ & Definition & Indicator \\
\hline Access & $\begin{array}{l}\text { Identifying the process } \\
\text { of receiving and } \\
\text { retrieving the } \\
\text { information }\end{array}$ & $\begin{array}{l}\text { Enter the class access code to access Schoology. } \\
\text { Open the quadratic function presented on GeoGebra through } \\
\text { the Schoology link. } \\
\text { - Press the home buttons, instructions, and sub-material } \\
\text { quadratic functions presented on GeoGebra. }\end{array}$ \\
\hline Manage & $\begin{array}{l}\text { Applying an existing } \\
\text { organizational or } \\
\text { classification scheme }\end{array}$ & $\begin{array}{l}\text { - Hit the checkbox, fill in the input box, and slide the sliders } \\
\text { available on GeoGebra }\end{array}$ \\
\hline Integrate & $\begin{array}{l}\text { Interpreting and } \\
\text { representing } \\
\text { information that has to } \\
\text { do with the ability to } \\
\text { summarize, compare } \\
\text { and contrast }\end{array}$ & $\begin{array}{l}\text { - Combine information related to the effects of } a, b, c \text { and } D \text { on } \\
\text { the graph of quadratic functions displayed on GeoGebra by } \\
\text { sliding the slider } \\
\text { Determine the quadratic function, the extreme point, the } \\
\text { symmetry axis, the maximum or minimum values, and the } \\
\text { intersection of the quadratic function to the X-axes and Y- } \\
\text { axes with the steps and graphs provided on GeoGebra. }\end{array}$ \\
\hline Evaluate & $\begin{array}{l}\text { Judging the relevance, } \\
\text { quality, and usefulness } \\
\text { of the information }\end{array}$ & $\begin{array}{l}\text { - Check the accuracy of the results of the testing media by } \\
\text { pressing the check button available on GeoGebra }\end{array}$ \\
\hline Create & $\begin{array}{l}\text { Generating information } \\
\text { by adapting, applying, } \\
\text { designing, inventing or } \\
\text { authoring information }\end{array}$ & $\begin{array}{l}\text { Use information obtained through GeoGebra by taking an } \\
\text { online learning outcomes test presented at Schoology }\end{array}$ \\
\hline
\end{tabular}

Schoology is used to present a variety of content that supports the learning process, such as learning video, practice exercise, and learning outcomes tests. GeoGebra software is 
used to provide quadratic function and integrated with Schoology in the form of a link. The material in the GeoGebra software is presented with two graphical views containing seven sub-sections in the first graphical display on the left and quadratic functions in the second graphical display on the right (See Figure 1).

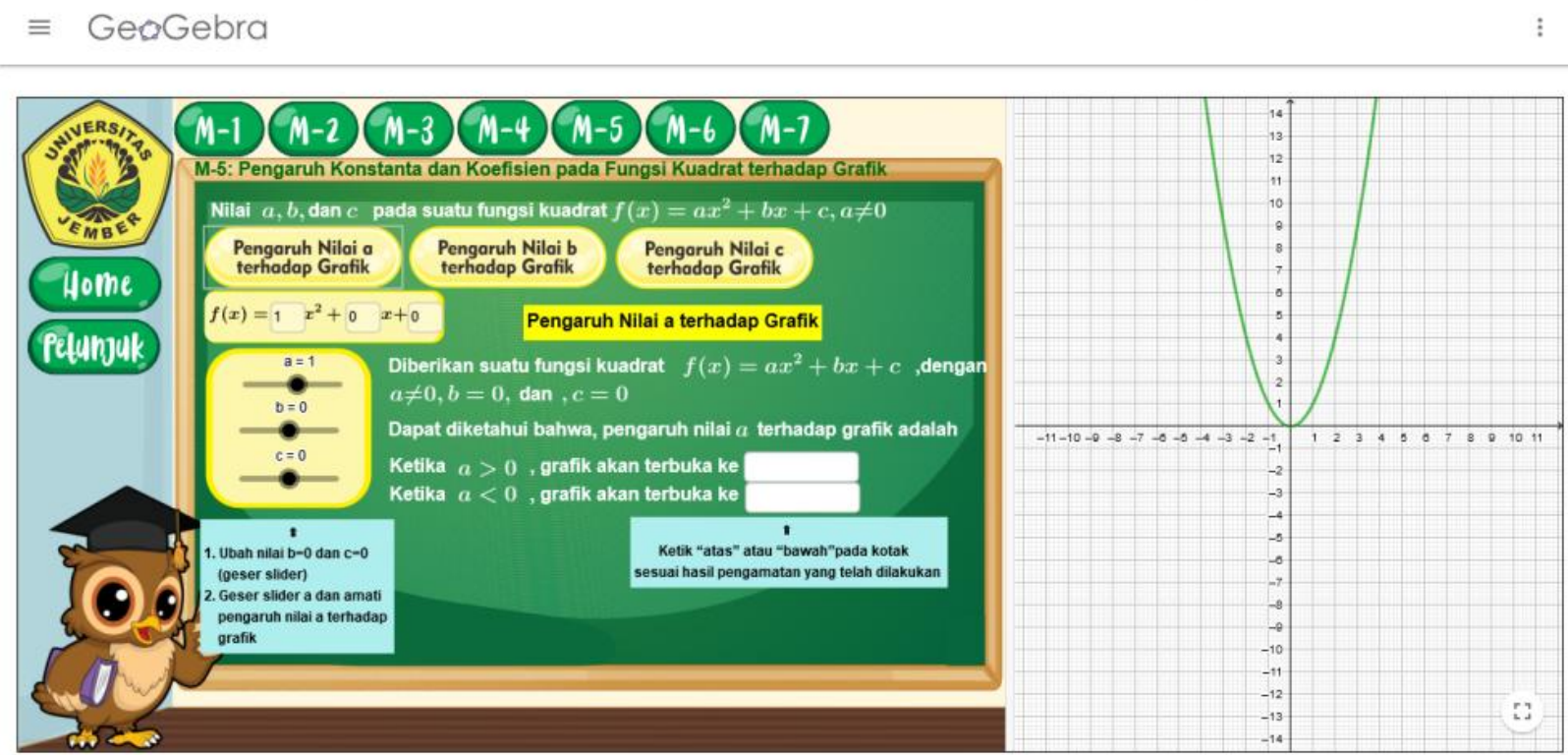

Figure 1. Display of learning media designed using GeoGebra

Figure 1 showed that there are seven buttons at the top of the media display. These buttons serve to present the quadratic function. The first sub-section (M-1) helps students understand quadratic functions, and both create and determine the coefficients and constants of a quadratic function. In the second sub-section (M-2), students can determine a quadratic function's discriminant function and the effect of the discriminant on a quadratic function graph by sliding the slider presented in the third sub-section (M-3). Whereas in the fourth sub-section (M-4), students can determine the extreme point, the symmetry axis, and the maximum/minimum value by calculations and provide the visualization on the quadratic function graph presented in the second graphical display directly. This media design provides students with an opportunity to develop their ideas and administer mathematical manipulation by sliding the slider presented in the fifth subsection (M-5). When the slider moves, students can see the effect of the coefficients and constants through the visualization of the graph $\mathrm{M}-5$, as seen in Figure 1 . In the sixth subsection (M-6), students can determine and identify the intersection of the quadratic function graph to the $\mathrm{X}$-axis and $\mathrm{Y}$-axis through the calculation and visualization of the graph. In the seventh sub-section (M-7), students can determine the function of the quadratic function graph displayed using the extreme point and one of the points chosen. Figure 1 shows various tools on GeoGebra that can improve ICT literacy and students' understanding of the material presented. These tools include buttons, input boxes, and sliders. The buttons are available to display sub-sections on the quadratic function and verify the students' answers. Input boxes are used to write the students' answers, while sliders use them to change the coefficients and constants of a quadratic function.

Furthermore, the preparation of learning outcomes test activity produces learning outcomes tests on quadratic function. The preparation of the tests has been discussed with a mathematics teacher and validated by experts. There are seven questions on the learning 
outcomes test in the form of multiple-choice and short answer related to a quadratic function. Multiple-choice questions are used to determine the students' understanding of the graphical characteristics of the quadratic function based on the selected answers in the form of graphs and graph characteristics. An example of a question in the form of multiplechoice is presented in Figure 2. This type of multiple-choice question is chosen because it can quickly analyze students' understanding of the material presented in the problem. Besides, the students' answers can be directly scored automatically using Schoology. Short entry questions are used to determine students' ability to write the final problem-solving results using a computer. This type of question is chosen because it makes it easier for students to write down the solutions to the problems given concisely. They do not need to write all the steps for completing it using a computer because it will take much time. Students are given a time limit to completing the test, as shown in Figure 2 (the timer is displayed in the lower right corner). The following is a sample of display the learning outcomes tests on Schoology.

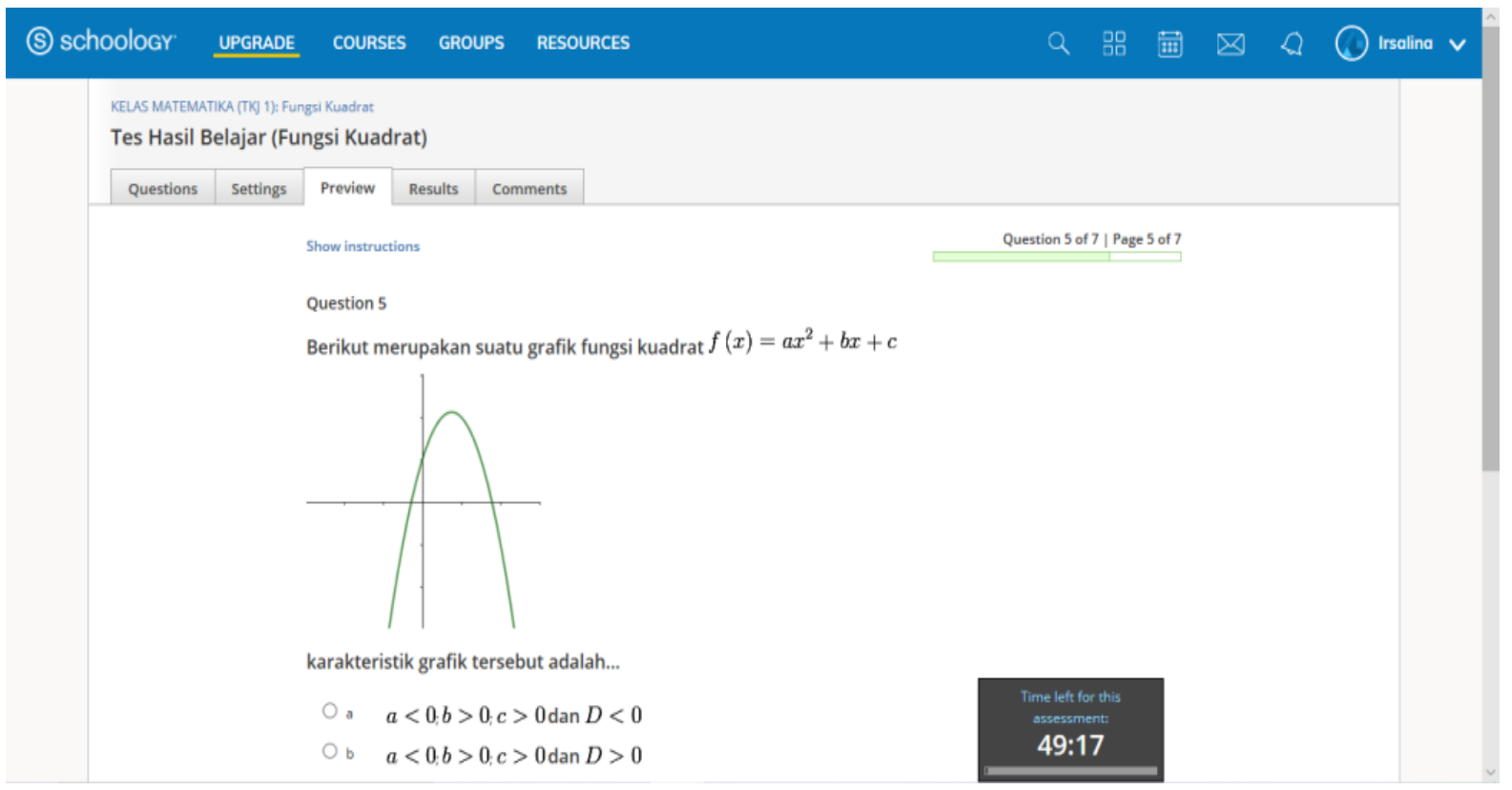

Figure 2. Learning outcomes test on Schoology

\section{Developing stage}

The developing stage consists of two activities: validation and media testing. The media developed is declared as valid based on the validation test so that it could be used to test the research subjects. The practicality and effectiveness of the media are determined from the results of the testing activity. The response from the media usage on the questionnaire and interviews also showed that the media is user-friendly. It is also found that the media meets the effective criteria based on learning outcomes tests and ICT literacy questionnaires.

\section{Disseminating stage}

The disseminating stage of learning media is carried out at the school through provisions of manuals to design and use Schoology web-based learning media on a 
quadratic function with GeoGebra software and learning media design on GeoGebra software. The media dissemination is also carried out through blogs and GeoGebra links.

\section{The validity of learning media}

Three aspects are defined as the validity of the media: content, language, and format. The maximum average of each aspect is 4 . Based on the two experts and one mathematics teacher validation, the average score of the content aspect is 3.96. It shows that the learning media's material has aligned with the content standards and the learning objectives. The validation results also showed that the language used in the media could be declared as communicative, with the average score of the language aspect being 3.67. It means that the users understand the material and the instructions provided. Media usage instructions, buttons, and images in the developed media design are said to be good quality, with an average score of the format aspect is 3.87. Thus, based on the validity results, it can be concluded that the media can be used to measure the students' ICT literacy.

\section{The practicality of learning media}

Based on the interview and response to the questionnaire, the instructional media were approved as practical, with a percentage of $89 \%$ practicality. Table 4 shows the indicators and response on the media usage questionnaire.

\section{Table 4}

Indicators of response on the media usage questionnaire

\begin{tabular}{|c|c|c|c|c|c|}
\hline \multirow{2}{*}{ No } & \multirow{2}{*}{ Indicator } & \multicolumn{4}{|c|}{$\begin{array}{c}\text { Percentage of The Students Response of } \\
\text { Each Category (\%) }\end{array}$} \\
\hline & & $\begin{array}{l}\text { Strongly } \\
\text { Agree }\end{array}$ & Agree & Disagree & $\begin{array}{l}\text { Strongly } \\
\text { Disagree }\end{array}$ \\
\hline 1. & $\begin{array}{l}\text { I can access Schoology by entering the class code } \\
\text { easily }\end{array}$ & 75.76 & 21.21 & 0.00 & 3.03 \\
\hline 2. & I can operate Schoology easily & 63.64 & 33.33 & 3.03 & 0.00 \\
\hline 3. & I can communicate through Schoology easily & 60.61 & 39.39 & 0.00 & 0.00 \\
\hline 4. & $\begin{array}{l}\text { I am interested in the learning achievement test } \\
\text { model using Schoology }\end{array}$ & 66.67 & 27.27 & 6.06 & 0.00 \\
\hline 5. & I can operate GeoGebra easily & 57.58 & 36.36 & 3.03 & 3.03 \\
\hline 6. & $\begin{array}{l}\text { I can understand the effect of values } a, b, c \text {, and D } \\
\text { on a quadratic function graph using GeoGebra }\end{array}$ & 54.55 & 45.45 & 0.00 & 0.00 \\
\hline 7. & $\begin{array}{l}\text { I can understand quadratic functions by using } \\
\text { GeoGebra }\end{array}$ & 57.58 & 36.36 & 3.03 & 3.03 \\
\hline 8. & $\begin{array}{l}\text { Learning by using this learning media is not } \\
\text { boring }\end{array}$ & 69.70 & 27.27 & 3.03 & 0.00 \\
\hline 9. & $\begin{array}{l}\text { I can solve problems with quadratic functions } \\
\text { after using GeoGebra }\end{array}$ & 57.58 & 36.36 & 6.06 & 0.00 \\
\hline 10. & $\begin{array}{l}\text { I get motivated to learn mathematics after using } \\
\text { this learning media }\end{array}$ & 54.55 & 27.27 & 15.15 & 3.03 \\
\hline
\end{tabular}

In Table 4, the students give a positive response to the learning media usage on each indicator. They are motivated to learn mathematics after using the learning media. They can easily use Schoology and GeoGebra. The test/quiz feature found in Schoology increases the students' interest in performing the learning outcomes test. The user-friendly features and the advantages of the learning media to visualize the graph make it easy for students to understand the quadratic function. The following are excerpts of the interviews by the researcher (R), student (S1), and teacher (T1). 
The interviews between the researcher and student

$P \quad$ : Do you understand the material easily after using the learning media?

S1 : Yes, I do. The media display the graph immediately, so I do not have to imagine it.

$P \quad:$ What is your first impression when using the media?

S1 : Fun, because it is different from previous learning. I also understand the material easily from the media.

The interviews between researcher and teacher

$P \quad$ : Do you think this media can help students understand the quadratic function easily?

T1 : Yes, because with GeoGebra, the quadratic function can be clearly described.

$P \quad: \quad$ After this lesson, will you use this media for the next study?

T1 : Yes, I will use the media in the learning process.

Based on the interview, it can be confirmed that the Schoology web-based learning media with GeoGebra can encourage the learning enjoyable and easier for students to understand the quadratic function.

\section{Effectiveness of learning media}

The effectiveness of learning media is obtained based on the N-Gain of learning outcomes test and ICT literacy questionnaire before and after using media. It is also supported by the results of observations of students' ICT literacy during the testing media. Table 5 shows that the $\mathrm{N}$-Gain of the students' learning outcomes test and ICT literacy questionnaire are 0.59 and 0.58 , respectively. Hence, the average value of $\mathrm{N}$-gain is 0.59 , which is in the range of $0.3 \leq \mathrm{g} \leq 0.7$. Based on the criteria in Table 2 , the category of media effectiveness is middle. Thus, the learning media can improve the students' ICT literacy.

Table 5

$\mathrm{N}$-Gain of the students' learning outcomes test and ICT literacy

\begin{tabular}{llll}
\hline Average of & $\begin{array}{l}\text { Before using the } \\
\text { media }\end{array}$ & $\begin{array}{l}\text { After using } \\
\text { the media }\end{array}$ & N-Gain \\
\hline ICT literacy ability & 2.87 & 3.53 & 0.58 \\
Learning outcomes test & 1.96 & 3.17 & 0.59 \\
& & Average N-Gain & 0.59 \\
\hline
\end{tabular}

Moreover, the ICT literacy questionnaires show that there is an improvement of each literacy component after using media. Table 6 shows the average value of $\mathrm{N}$-Gain on each ICT literacy component.

Table 6

N-Gain on each ICT literacy component

\begin{tabular}{lccc}
\hline Component & $\begin{array}{c}\text { Average of ICT literacy } \\
\text { before using the media }\end{array}$ & $\begin{array}{l}\text { Average of ICT literacy } \\
\text { after using the media }\end{array}$ & N-gain \\
\hline Access & 2.95 & 3.60 & 0.62 \\
Manage & 2.67 & 3.48 & 0.61 \\
Integrate & 2.89 & 3.51 & 0.56 \\
Evaluate & 2.95 & 3.55 & 0.57 \\
Create & 2.89 & 3.52 & 0.57 \\
\hline
\end{tabular}

Table 6 presented the average value of each component of ICT literacy before and after using learning media. Table 6 also showed that the $\mathrm{N}$-gain for each component in the range of $0.3 \leq \mathrm{g} \leq 0.7$, which is the middle category. Thus, the learning media can improve the students' ICT literacy. 
The development of learning media using Schoology and GeoGebra software is carried out to improve the students' ICT literacy. The teachers and students provide a positive response to the learning media produced. This media can make learning enjoyable and comfortable for students to understand the quadratic function. According to Jan (2018), learning by utilizing technology can create a more collaborative and engaging learning environment.

The learning media developed not only makes it easy to understand the material presented but also improves the students' ICT literacy (See Table 6). There has been an improvement in each component of ICT literacy including access, manage, integrate, evaluate, and create. Students can understand the process of retrieving learning information using the learning media. They can access Schoology easily by entering the class access code and open and press the buttons available on GeoGebra linked to Schoology to get available learning information. However, some students are unable to access Schoology and GeoGebra properly. It is due to the poor internet connection, which affects the process of retrieving learning information. It is also confirmed by Umar and Jalil (2020), who stated that the internet facility contributes to develop student abilities in using the computer. Besides, this media is equipped with instructions to use the media, which helps improve the management components in the students' ICT literacy. This instruction makes it easy for the students to operate so that this media is the appropriate technological device to improve the students' ICT literacy (Jan, 2018).

Learning media with GeoGebra can help students understand the material. GeoGebra can visualize the mathematical concepts, so it can be used to explore and investigate the characteristics of a graph. With this software, students can learn mathematics easily (Hohenwarter \& Fuch, 2004; NTCM, 2000; Ozdamli, Karabey, \& Nizamoglu, 2013). By using the sliders found in M-3 and M-5 (See Figure 1), students can change the coefficients and constants of a quadratic function by moving the slider using the mouse. Through quick and precise visualization of graphs, students can retrieve information related to the effects of coefficients, constants, and discriminant on quadratic functions. The advantage of the media use and ease of operation can improve the students' ICT literacy in interpreting the information obtained from the material presented. Additionally, this media is equipped with a check button that can be used to verify students' manipulation and exploration results. Students can easily assess the relevance of the work results and the correctness of answers.

The utilization of test/quiz facilities in Schoology is quite effective in improving the students' ICT in the create component. Students can write or solve the learning outcomes test given in Schoology. The utilization of technology in learning can encourage students to investigate, help students seek the information, find and understand the material, define mathematical procedures/processes, design, and produce representations of their knowledge (Dhayanti et al., 2018).

Learning media with technology makes students easier to understand the material. However, it will be difficult for the students to retrieve the learning information without supported ICT literacy. The students' ICT literacy can be trained and improved using technology based on the results of tests. Besides, students' ICT literacy can also affect their learning outcomes (Markauskaite, 2006).

Learning media that meets valid, practical, and effective criteria can improve the students' ICT literacy. Dhayanti et al. (2018) stated that the use of software and interactive classroom atmosphere could achieve learning objectives. Dhayanti's ( $\underline{2018})$ statement is 
consistent with the previous development research that the media will be appropriate to be used in the learning process if it meets all three criteria (Eliana et al., 2016; Murtikusuma, Fatahillah, et al., 2019).

\section{Conclusion}

The process of media development consists of four stages: defining, designing, developing, and disseminating. It produced web-based learning media for Schoology with GeoGebra software on quadratic functions, which is valid, practical, and effective. Media validity is obtained from the validation results of the three experts. The practicality is derived from the response of the media usage questionnaire, supported by interviews with the students and teachers. An average N-gain shows the effectiveness of the media from the learning outcomes test and questionnaire. Students' ICT literacy can enhance the use of technology in the learning process. Schoology web-based learning media with GeoGebra software is one of the media by utilizing appropriate technology in the learning process to enhance students' ICT literacy.

\section{Acknowledgment}

The authors would like to acknowledge the participation of the students in this study. We want to thank the validators for their support in checking the media so that it can be used to improve students' ICT literacy.

\section{Bibliography}

Arbain, N., \& Shukor, N. A. (2015). The Effects of GeoGebra on Students Achievement. Procedia - Social and Behavioral Sciences, 172, 208-214. https://doi.org/10.1016/i.sbspro.2015.01.356

Bernard, M., \& Senjayawati, E. (2019). Developing the Students ' Ability in Understanding Mathematics and Self-confidence with VBA for Excel. JRAMathEdu Journal of Research and Advances in Mathematics Education), 4(1), 45 - 56. https://doi.org/10.23917/jramathedu.v4i1.6349

Dhayanti, D., Johar, R., \& Zubainur, C. M. (2018). Improving Students ' Critical and Creative Thinking through Realistic Mathematics Education using Geometer' s Sketchpad. JRAMathEdu (Journal of Research and Advances in Mathematics Education), 3(1), 2535. https://doi.org/10.23917/iramathedu.v3i1.5618

Educational Testing Service (ETS). (2002). Digital Transformation: A framework for ICT literacy.

Retrieved

from http://www.ets.org/Media/Tests/Information and Communication Technology Lite racy/ictreport.pdf

Eliana, E. D. S., Senam, Wilujeng, I., \& Jumadi. (2016). The effectiveness of project-based elearning to improve ICT literacy. Jurnal Pendidikan IPA Indonesia, 5(1), 51-55. https://doi.org/10.15294/jpii.v5i1.5789

Garba, S. A. (2014). Impact of ICT Course on Pre-Service Teachers Acquisition of ICT Literacy Skills and Competence in Nigeria. International Journal of Modern Education Research, 1(2), 37-42. Retrieved from https://www.researchgate.net/publication/273593700

Ghavifekr, S., \& Rosdy, W. A. W. (2015). Teaching and Learning with Technology: Effectiveness of ICT Integration in Schools. International Journal of Research in 
Education and Science, 1(2), 175. https://doi.org/10.21890/ijres.23596

Hake, R. R. (1999). Analyzing change/gain scores. Unpublished.[Online]. Retrieved from https://www1.physics.indiana.edu/ sdi/AnalyzingChange-Gain.pdf

Hohenwarter, M., \& Fuch, K. (2004). Combination of dynamic geometry, algebra and calculus in the software system GeoGebra.

Jan, S. (2018). Investigating the relationship between students' digital literacy and their attitude towards using ICT. International Journal of Educational Technology, 5(2), 2634 .

Retrieved

from https://educationaltechnology.net/ijet/index.php/ijet/article/view/35

Joshua, J. W. N., Kom, S., \& Si, M. (2015). The Effectiveness of E-Learning Implementation Using Social Learning Network Schoology on Motivation \& Learning Achievement in STMIK Primakara Bali. Jurnal Nasional Pendidikan Teknik Informatika, 5(1), 28-33.

Koklu, O., \& Topcu, A. (2012). Effect of Cabri-assisted instruction on secondary school students' misconceptions about graphs of quadratic functions. International Journal of Mathematical Education in Science and Technology, 43(8), 999-1011. https://doi.org/10.1080/0020739X.2012.678892

Kristanto, Y. D., Amin, S. M., \& Khabibah, S. (2016). The Development of Investigative Learning Materials Using Computer Assisted Instruction in the Topic of Reflection for Grade VII. Journal of Research and Advances in Mathematics Education, 1(2), 172-182.

Markauskaite, L. (2006). Towards an integrated analytical framework of information and communications technology literacy: From intended to implemented and achieved dimensions. Information Research, 11(3), 31-53.

Murtikusuma, R. P., Fatahillah, A., Oktavianingtyas, E., Hussen, S., \& Lailiya, N. (2019). The development of interactive mathematics learning media based on schoology and visual basic through industrial revolution 4.0. IOP Conference Series: Earth and Environmental Science, 243(1), 0-6. https://doi.org/10.1088/1755$1315 / 243 / 1 / 012137$

Murtikusuma, R. P., Hobri, Fatahillah, A., Hussen, S., Prasetyo, R. R., \& Alfarisi, M. A. (2019). Development of blended learning based on Google Classroom with osing culture theme in mathematics learning. Journal of Physics: Conference Series, 1165(1). https://doi.org/10.1088/1742-6596/1165/1/012017

NTCM. (2000). Principles and Standards for School Mathematics. United States of America: NTCM.

Nurhabibah, Setiawan, A., Yanti, H., Miraj, Y. Z., \& Yannuar. (2018). Analysis of ICT Literacy Competence among Vocational High School Teachers. IOP Conference Series: Materials Science and Engineering, 306(1). https://doi.org/10.1088/1757899X/306/1/012097

Oktavianingtyas, E., Salama, F. S., Fatahillah, A., Monalisa, L. A., \& Setiawan, T. B. (2018). Development 3D Animated Story as Interactive Learning Media with Lectora Inspire and Plotagon on Direct and Inverse Proportion Subject. Journal of Physics: Conference Series, 1108(1). https://doi.org/10.1088/1742-6596/1108/1/012111

Ozdamli, F., Karabey, D., \& Nizamoglu, B. (2013). The Effect of Technology Supported Collaborative Learning Settings on Behaviour of Students Towards Mathematics Learning. Procedia - Social and Behavioral Sciences, 83, 1063-1067. https://doi.org/10.1016/j.sbspro.2013.06.198

Pernia, E. (2008). Strategy framework for promoting ICT literacy in the Asia-Pacific region. Bangkok:

UNESCO

Bangkok.

Retrieved

from 
https://unesdoc.unesco.org/ark:/48223/pf0000162157

Pratolo, B. W., \& Solikhati, H. A. (2020). The implementation of digital literacy in indonesian suburban EFL classes. International Journal of Scientific and Technology Research, 9(1), 1508-1512.

Rohaeti, E. E., Bernard, M., \& Primandhika, R. B. (2019). Developing interactive learning media for school level mathematics through open-ended approach aided by visual basic application for excel. Journal on Mathematics Education, 10(1), 59-68. https://doi.org/10.22342/jme.10.1.5391.59-68

Saha, R. A., Ayub, A. F. M., \& Tarmizi, R. A. (2010). The effects of GeoGebra on mathematics achievement: Enlightening Coordinate Geometry learning. Procedia - Social and Behavioral Sciences, 8, 686-693. https://doi.org/10.1016/i.sbspro.2010.12.095

Şandır, H., \& Aztekin, S. (2016). Pre-service math teachers' opinions about dynamic geometry softwares and their expectations from them. Mathematics Education, 11(3), 421-431.

Setyaningrum, W. (2018). Blended Learning: Does it help students in understanding mathematical concepts? Jurnal Riset Pendidikan Matematika, 5(2), 244-253. https://doi.org/10.21831/irpm.v5i2.21428

Shadaan, P., \& Eu, L. K. (2013). Effectiveness of Using GeoGebra on Students' Understanding in Learning Circles. Malaysia Online Journal of Educational Techology, 1(4), 1-11.

Sriyanto, W., \& Kaniadewi, N. (2019). Using Schoology in the Era of IR 4.0 (Factors Analysis From Students' Perception). International Journal for Educational and Vocational Studies, 1(5), 451-454. https://doi.org/10.29103/ijevs.v1i5.1573

Tadesse, T., Gillies, R. M., \& Campbell, C. (2018). Assessing the dimensionality and educational impacts of integrated ICT literacy in the higher education context. Australasian Journal of Educational Technology, 34(1), 88-101. https://doi.org/10.14742/ajet.2957

Thammasaeng, P., Pupat, P., \& Petchaboon, S. (2016). Needs assessment of information and communication technology literacy (ICT literacy) of students in secondary educational service area. International Journal of Emerging Technologies in Learning, 11(12), 9-13. https://doi.org/10.3991/ijet.v11i12.5798

Thiagarajan, S., Semmel, D. I., \& Semmel, M. I. (1974). Instructional Development for Training Teachers of Exceptional Children: A Sourcebook. Journal of School Psychology, 14(1), 75. https://doi.org/10.1016/0022-4405(76)90066-2

Umar, I. N., \& Jalil, N. A. (2020). ICT skills, practices and barriers of its use among secondary school students. 46, 5672-5676. https://doi.org/10.1016/i.sbspro.2012.06.494

Wahyu, K., Ratnasari, D., Mahfudy, S., \& Etmy, D. (2019). Mathematics Teachers and Digital Technology: A Quest for Teachers ' Professional Development in Indonesia. JRAMathEdu (Journal of Research and Advances in Mathematics Education), 4(1), 31 44. https://doi.org/10.23917/jramathedu.v4i1.7547 